\title{
KEBUTUHAN IKAN BAHAN BAKU INDUSTRI PINDANG DI PELABUHAN PERIKANAN PANTAI TASIK AGUNG REMBANG
}

\author{
Demand for Fish Raw Material in the Boiled Fish Processing Industries at the Coastal \\ Fishing Port of Tasik Agung Rembang \\ Oleh: \\ Ernani Lubis ${ }^{1 *}$, Anwar Bey Pane ${ }^{1}$, Khoerul Fatoni ${ }^{2}$ \\ ${ }^{1}$ Departemen Pemanfaatan Sumberdaya Perikanan Fakultas Perikanan dan Ilmu Kelautan, Institut Pertanian Bogor. \\ ernani_ipb@yahoo.com; beypane_sibolga@yahoo.fr \\ 2 Departemen Pemanfaatan Sumberdaya Perikanan Fakultas Perikanan dan Ilmu Kelautan, Institut Pertanian Bogor. \\ Khoerul_fatoni@apps.ipb.ac.id \\ *Korespondensi:ernani_ipb@yahoo.com
}

Diterima: 20 Agustus 2019; Disetujui: 21 Oktober 2019

\begin{abstract}
Fishing port plays a vital role in providing fish raw materials (IBB) required for fish processing industries (IPI). The planning and development of IPI at Tasik Agung Rembang Coastal Fishing Port (PPP) rely on information regarding IBB supplies, however little data is available to support the decision. The purpose of this study was to investigate the origin of the IBB in fulfilling IPI demand for Pindang production and assess the IBB actual supplies (type, number, quality). A survey on the availability of IBB was conducted by involving various stakeholders including port officers, fishers, and IPI related entrepreneurs. Data collection consisted of both demand and supplies of IBB, which incorporate types, volume, and quality of fish. The results showed that the total demand for IBB was 824.8 ton/month and consisted of 9 species. However, the existing supplies of IBB only cover $59.5 \%$ of it.
\end{abstract}

Keywords: raw materials, pindang, Tasik Agung fishing port

\begin{abstract}
ABSTRAK
Pelabuhan perikanan berperan dalam penyediaan kebutuhan ikan sebagai bahan baku (ikan bahan baku/IBB) bagi industri pengolahan ikan (IPI). Kebutuhan IBB sangat diperlukan untuk perencanaan dan pengembangan IPI di Pelabuhan Perikanan Pantai (PPP) Tasik Agung Rembang. Akan tetapi data terkait ketersediaan IBB PPP Tasik Agung Rembang termasuk sumber pemenuhan kebutuhan IBB, belum diketahui. Tujuan penelitian ini adalah untuk mengetahui asal sumber pemenuhan IBB untuk IPI pindang dan mengetahui kebutuhan IBB (jenis, jumlah, kualitas). Penelitian dilakukan dengan cara melakukan survei ketersediaan IBB untuk IPI pindang di PPP Tasik Agung dan IPI pindang di sekitar PPP Tasik Agung, dengan melibatkan responden baik dari pengelola pelabuhan, nelayan, maupun pengusaha pengolahan ikan pindang yang keberadaanya di sekitar PPP Tasik Agung. Jenis data yang digunakan yaitu jenis, volume dan mutu ikan bahan baku industri pindang yang tersedia di PPP Tasik Agung dan yang dibutuhkan oleh industri pengolah ikan pindang di sekitar PPP Tasik Agung. Hasil penelitian menunjukkan bahwa kebutuhan IBB IPI pindang di PPP Tasik Agung berjumlah 824,8 ton/bulan dan terdiri dari 9 jenis ikan yaitu layang,
\end{abstract}


kembung, salem, siro, tongkol, bentong, selar, peperek, dan tembang. Kebutuhan IBB IPI pindang hanya terpenuhi sebesar 490,9 ton/bulan $(59,5 \%)$ dari yang dibutuhkan.

Kata kunci: bahan baku, pindang, Pelabuhan Perikanan Tasik Agung

\section{PENDAHULUAN}

Ikan pindang cukup populer di Indonesia terutama di Pulau Jawa. Ikan ini banyak digemari oleh masyarakat Indonesia, rasanya enak, relatif tahan lama, dan harganya cukup murah/ terjangkau. Sebagai contoh ikan pindang di Kabupaten Rembang pada tahun 2017 dapat dibeli dengan harga Rp 13.000-20.000/12 besek (Naya et al. 2017), dan harga jual ikan pindang di Kabupaten Sumenep sebesar Rp 20.000/kg (Ridho 2019). Produk pindang yang dihasilkan juga dapat langsung dimakan (ready to eat), sehingga sangat praktis dan mudah untuk dikonsumsi.

Produk ikan pindang adalah ikan yang dihasilkan dari proses pengolahan melalui perebusan ikan basah yang diberi sejumlah garam (Setiani et al. 2019); pengolahannya termasuk jenis pengolahan tradisional (Assadad \& Utomo 2011; Adrian, 2013), banyak dikenal oleh masyarakat, merupakan pengolahan ikan yang mudah dan praktis (Hamzah et al. 2015) serta dapat menggunakan berbagai jenis ikan. Produksi ikan pindang di Indonesia per Oktober 2013 mencapai 242.159 ton atau 95,49\% dari target capaian produksi ikan pindang pada tahun 2013 (Ratri 2013). Jumlah industri pengolahan ikan pindang (IPI) pindang di Indonesia sudah mencapai 11.561 unit pada tahun 2017 (Widria 2019).

Salah satu peran penting pelabuhan perikanan (PP) selain sebagai penyedia ikan basah untuk kebutuhan konsumsi masyarakat, juga sebagai penyedia ikan basah untuk kebutuhan industri pengolahan ikan (IPI) di pelabuhan dan sekitarnya; yang diperkuat secara tersirat pada Undang-undang Republik Indonesia No. 45 Tentang Perikanan Tahun 2009 pasal 1 ayat 1, pasal 25, pasal 41A ayat 1, (Setneg RI 2009), dan Peraturan Menteri Kelautan dan Perikanan No.08 Tahun 2012 Tentang Kepelabuhanan Perikanan pasal 1 ayat 16 , pasal 3 ayat 1 dan ayat 7 butir c. (KKP 2012).

Pelabuhan Perikanan Pantai (PPP) Tasik Agung Rembang merupakan penyedia ikan basah utama bagi IPI termasuk pindang di Kabupaten Rembang (DKP Kabupaten Rembang 2018). Kabupaten Rembang merupakan salah satu sentra pengolahan pindang terbesar di Provinsi Jawa Tengah, dengan jumlah unit pengo- lahan sebanyak 240 unit dari 1960 unit pengolahan pindang di Provinsi Jawa Tengah pada tahun 2011 (KKP 2013). Pada tahun 2017 produksi pindang di Kabupatan Rembang adalah 54.479 ton (DKP Kabupaten Rembang 2018). Produk pindang memiliki kontribusi terbesar dalam produksi hasil pengolahan ikan di Tasik Agung (Adhitama 2018). Dapat dikatakan bahwa produk pindang merupakan produk primadona untuk olahan ikan di Tasik Agung.

Tingginya produksi pindang di Tasikagung, mengakibatkan kebutuhan suplai ikan bahan baku (IBB) pindang perlu mendapat perhatian khusus. Selama ini, pengolah ikan pindang memperoleh IBB dari PPP Tasik Agung. Berdasarkan hasil wawancara awal dengan pengelola pelabuhan, kebutuhan IBB para pengolah ikan pindang yang mengandalkan sumber bahan bakunya dari PPP Tasik Agung, belum diketahui. Kebutuhan IBB yang dimaksud adalah terkait dengan informasi tentang jenis, jumlah dan mutu ikan yang menjadi bahan baku bagi industri pengolahan ikan (IPI) pindang. Selama ini, pihak IPI hanya mencari IBI berdasarkan jenis, jumlah dan mutu ikan yang tersedia di PPP Tasik Agung. Terkadang kekurangan jumlah ikan, akan dicarikan di tempat lain. Sebenarnya, sudah menjadi tugas pelabuhan untuk dapat mendukung kebutuhan bahan baku industri perikanan salah satunya adalah IPI pindang, yang berada di lingkup kerjanya. Akan tetapi, ketiadaan informasi terkait jumlah, jenis dan mutu ikan yang diharapkan oleh para pengolah ikan pindang, mengakibatkan pihak PPP Tasik Agung mengalami kesulitan dalam pengelolaan yang terkait dengan dukungan pelabuhan terhadap ketersediaan IBI bagi IPI pindang. Apabila ketersediaan IBI di PPP Tasik Agung tidak segera dikelola dengan baik, dikhawatirkan kegiatan IPI pindang menjadi tidak stabil. Bahkan sudah terjadi beberapa industri pengolahan pindang di sekitar PPP Tasik Agung yang terpaksa menghentikan produksinya. Hal ini dikarenakan ketiadaan modal pengusaha untuk mendatangkan bahan baku dari luar PPP Tasik Agung. Ketidakstabilan ketersediaan IBI, akan mengakibatkan produksi IPI menjadi tidak stabil, baik dari segi jumlah produksi maupun mutu yang diharapkan. Hal inipun akan berdampak pada menurunnya permintaan ikan pindang yang berasal dari Tasik 
Agung, dikarenakan konsumen mulai beralih ke produsen dari daerah lainnya.

Estimasi jumlah kebutuhan IBB bagi IPI pindang di PPP Tasik Agung dan sekitarnya adalah sangat penting untuk diketahui, agar dapat dilakukan perencanaan penyediaannya oleh pihak PPP Tasik Agung, dan juga nantinya akan berguna bagi pengembangan IPI pindang di PPP Tasik Agung. Berdasarkan permasalahan di atas, maka penelitian ini dilakukan dengan tujuan untuk mengidentifikasi sumber pemenuhan kebutuhan IBB IPI pindang di PPP Tasikagung Rembang, serta mengestimasi kebutuhannya ikan bahan baku untuk industri pindang (jenis, jumlah, mutu) di Tasik Agung.

\section{METODE}

Penelitian lapang dilakukan pada bulan Februari-Maret 2018 di PPP Tasik Agung Rembang dan IPI pindang di sekitarnya. Penelitian dilakukan dengan cara survei ke PPP Tasikagung dan industri pengolahan ikan pindang di sekitar PPP Tasik Agung. Pengumpulan data dilakukan dengan cara wawancara yang dilengkapi dengan kuisioner dan lembaran scoresheet untuk pengukuran mutu IBB pindang di unit IPI pindang sampel. Jenis data utama yang dikumpulkan terdiri dari data yang berupa informasi sumber IBB bagi IPI di Tasik Agung, jenis ikan, jumlah ikan per jenis serta standar mutu IBI yang diharapkan oleh IPI; serta jenis, jumlah dan mutu ikan bahan baku industri pengolahan ikan yang tersedia di PPP Tasik Agung.

Pengumpulan data sekunder dilakukan di PPP Tasik Agung, dan Dinas Kelautan dan Perikanan (DKP) Kabupaten Rembang meliputi jenis-jenis produksi ikan didaratkan tahun 2017, data bulanan kebutuhan IBB IPI pindang tahun 2017, dan jumlah unit pengolahan ikan pindang tahun 2018. Wawancara dilakukan terhadap 30 responden (4 responden dari empat sampel unit industri dari 7 unit IPI pindang yang aktif di sekitar pelabuhan, 6 responden pengelola pelabuhan dan DKP Kabupaten Rembang, 10 responden pedagang ikan dan 10 responden nelayan); penentuan responden menggunakan metode purposive sampling. Kesemua responden adalah yang melakukan aktivitas di PPP Tasikagung atau terkait dengan aktivitas di PPP Tasik Agung.

Pengukuran mutu IBB dilakukan menggunakan metode uji organoleptik menurut BSN 2013, yaitu terhadap mata, insang, konsistensi otot, dan daging dan perut ikan, di empat sampel unit IPI pindang di atas. Pemilihan jenis ikan didasarkan pada hasil wawancara kepada responden IPI pindang dan kebutuhan IPI pindang di PPP Tasik Agung. Penentuan sampel ikan untuk pengamatan mutu, dilakukan secara acak, dan ketika sebagian besar nilai organoleptik ikan sudah homogen maka jumlah sample dicukupkan. Pada akhirnya, pengukuran mutu IBB dilakukan terhadap 460 ekor; terdiri dari 100 ekor layang (Decapterus macrosoma), 85 ekor kembung (Restrelliger brachysoma), 20 ekor bentong (Selar leptolepis), 100 ekor salem (Scomber japonicas), 60 ekor siro (Amblygaster sirm), 25 ekor selar (Selaroides leptolepis), 25 ekor tongkol (Auxis thazard), 25 ekor tembang (Sardinella fimbriata) dan 20 ekor peperek (Leiognathus equulus). Mutu IBB adalah sesuai dengan besaran mutu ikan yang terdapat dan diukur di IPI pindang di PPP Tasik Agung, yang pada dasarnya diasumsikan sesuai dengan permintaan konsumen/pasar. Kategori kebutuhan IBB dibagi dua yaitu kebutuhan IBB yang diharapkan untuk diproduksi, dan kebutuhan IBB yang terpenuhi.

Asal sumber pemenuhan kebutuhan IBB IPI pindang, dan kebutuhannya, dianalisis secara deskriptif kualitatif dan deskriptif kuantitatif melalui perhitungan jumlah, rata-rata, kisaran, simpangan (varians), sajian tabel, gambar/peta/ skema grafik dan analisis grafik terhadap data jenis dan jumlah ikan bahan baku pada saat penelitian (2018).

\section{HASIL}

\section{Sumber Pemenuhan Kebutuhan Ikan Bahan Baku pada Industri Ikan Pindang di PPP Tasik Agung Rembang}

Berdasarkan hasil penelitian, diketahui bahwa terdapat 8 (delapan) dari 24 jenis ikan yang didaratkan di PPP Tasik Agung, digunakan sebagai IBB oleh IPI pindang, yaitu layang, kembung, siro, tongkol, bentong, selar, peperek, dan tembang. Volume produksi ke-8 jenis ikan didaratkan tersebut mewakili $4.076,3$ ton atau $62,2 \%$ dari seluruh produksi ikan didaratkan di pelabuhan (6.556,7 ton) pada tahun 2017 (PPP Tasik Agung 2018). Keseluruhan produksi ikan tersebut didaratkan oleh armada penangkapan ikan kapal motor (KM) mini purse seine (645 unit; $60,2 \%$ ) dan cantrang (427 unit; 39,8\%) pada tahun yang sama; baik oleh KM yang berpangkalan di pelabuhan ini maupun KM pendatang (DKP Kabupaten Rembang 2018). Kedelapan jenis IBB IPI pindang didapatkan dari berbagai sumber pemenuhan kebutuhan IBB.

Sumber pemenuhan kebutuhan IBB pada IPI pindang di PPP Tasik Agung Rembang berasal dari dalam dan dari luar pelabuhan 
(Gambar 1). Sumber pemenuhan kebutuhan IBB yang berasal dari dalam PPP Tasik Agung Rembang, sebagian besar diperoleh dari ikan hasil tangkapan yang didaratkan di PPP Tasik Agung. Sumber pemenuhan kebutuhan IBB lainnya berasal dari luar pelabuhan yang dibawa oleh pedagang grosir, dan pedagang pengumpul dari pelabuhan perikanan lainnya di sekitar Kabupaten Rembang yaitu PPI Sarang, PPI Karanganyar, dan PPP Bajomulyo, selain juga dari pedagang ikan salem di luar Kabupaten Rembang yaitu pedagang dari Juwana, Jakarta, dan Surabaya. Hal ini juga sering dilakukan oleh pelabuhan perikanan di Prancis untuk menambah IBB bagi IPI di suatu pelabuhan perikanan seperti halnya yang terjadi di Pelabuhan Perikanan Boulogne-Sur-Mer (Lubis 2012). Industri pengolahan pindang di PPP Tasik Agung ini, selain menggunakan ke-8 jenis IBB sebagaimana telah disebutkan di atas, juga menggunakan ikan salem yang diimpor dari Cina.

Jumlah kebutuhan seluruh jenis IBB IPI pindang di PPP Tasik Agung adalah 824,8 ton/ bulan, sedangkan jumlah IBB yang diperoleh oleh IPI pindang hanya terpenuhi 490,9 ton/ bulan atau sekitar $59,5 \%$ dari jumlah kebutuhan IBB IPI pindang di pelabuhan ini (Gambar 2); dengan demikian sebanyak $40,5 \%$ kebutuhan IBB pindang belum terpenuhi. Banyaknya jumlah kebutuhan IBB pindang yang belum terpenuhi mengakibatkan para pengusaha IPI pindang di PPP Tasik Agung harus mencari alternatif pemenuhan kebutuhan IBB pindang kepada para pedagang penyuplai IBB dari pelabuhan-pelabuhan perikanan lainnya, bahkan kepada para pedagang importir ikan salem.

Gambar 3 memperlihatkan bahwa sebanyak $50,8 \%$ atau 249,4 ton/bulan dari jumlah IBB pindang yang terpenuhi (490,9 ton/bulan) berasal dari luar PPP Tasik Agung. Persentase tersebut relatif sedikit lebih tinggi dibandingkan dengan persentase IBB yang berasal dari dalam PPP Tasik Agung yaitu 49,2\% atau 241,5 ton/ bulan. Ikan bahan baku yang didatangkan dari daerah lain oleh IPI pindang, sebagaimana ikan salem asal impor, juga dilakukan karena ketersediaan IBB utama untuk IPI pindang yaitu jenis ikan layang di PPP Tasik Agung Rembang tidak mencukupi untuk kebutuhan IPI pindang di pelabuhan ini.

Pada Gambar 4 menunjukkan bahwa ikan jenis layang merupakan jenis IBB IPI pindang yang paling banyak didapatkan dari dalam PPP Tasik Agung, dengan jumlah 71,4 ton/bulan atau $29,6 \%$ dari jumlah IBB yang dipenuhi dari dalam pelabuhan ini. Hal ini sejalan dengan pendapat Nababan et al. (2014) sebelumnya bahwa ikan layang yang didaratkan di TPI I PPP Tasik Agung merupakan komoditas ikan yang paling dominan sebagai IBB IPI pindang pada tahun 2013. Dapat dikatakan bahwa sejak tahun 2013 sampai tahun 2018, ikan jenis layang merupakan IBB dominan untuk IPI pindang di PPP Tasik Agung.

Jenis IBB yang didatangkan dari luar PPP Tasik Agung terdiri dari 6 jenis dari 9 jenis ikan yang dapat digunakan sebagai IBB IPI pindang. Jenis ikan salem (Scomber japonicus) merupakan ikan yang paling banyak didatangkan dari luar PPP Tasik Agung, yaitu asal impor dari Cina, dengan jumlah 97,1 ton/bulan atau $38,9 \%$ dari jumlah IBB yang didatangkan dari luar PPP Tasik Agung (Gambar 5). Jenis ikan lainnya yang didatangkan dari luar pelabuhan seperti layang $(30,9 \%)$, kembung $(12,6 \%)$, siro $(9,1 \%)$, tongkol $(4,2 \%)$, dan bentong (4,2\%) didatangkan dari daerah Sarang, Karanganyar dan Juwana.

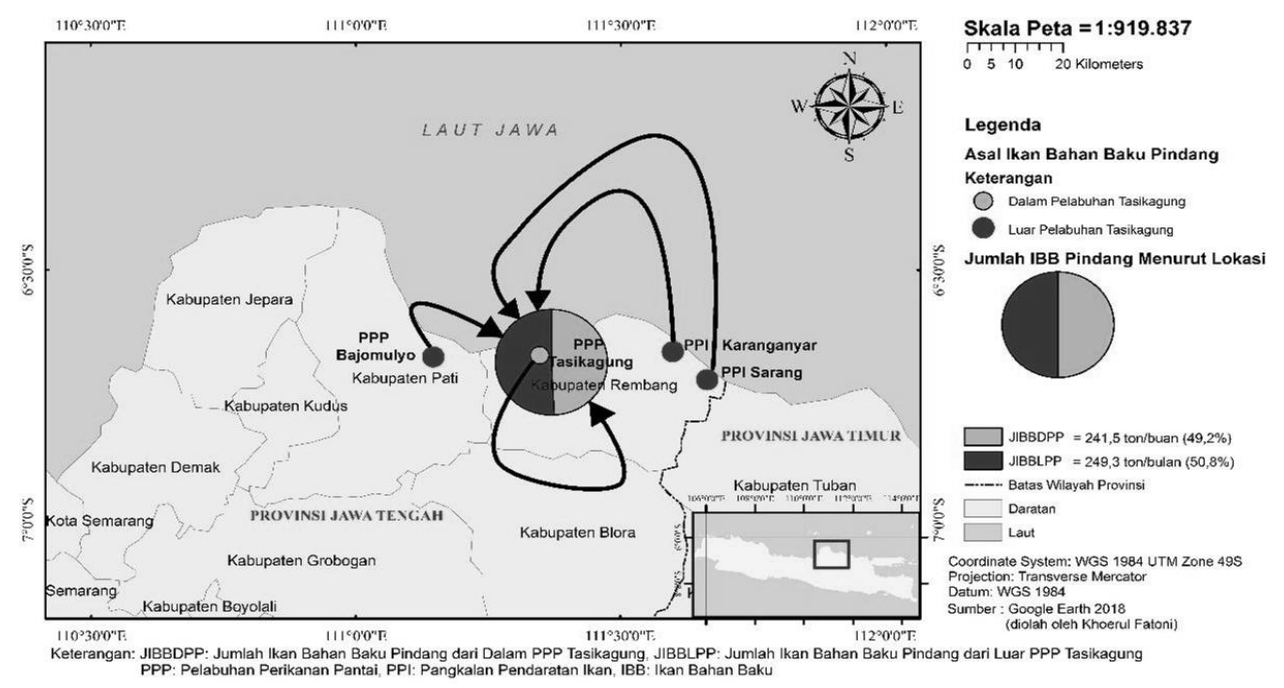

Gambar 1 Peta sumber pemenuhan ikan bahan baku pada industri ikan pindang di PPP Tasik Agung menurut asal lokasi tahun 2018. 


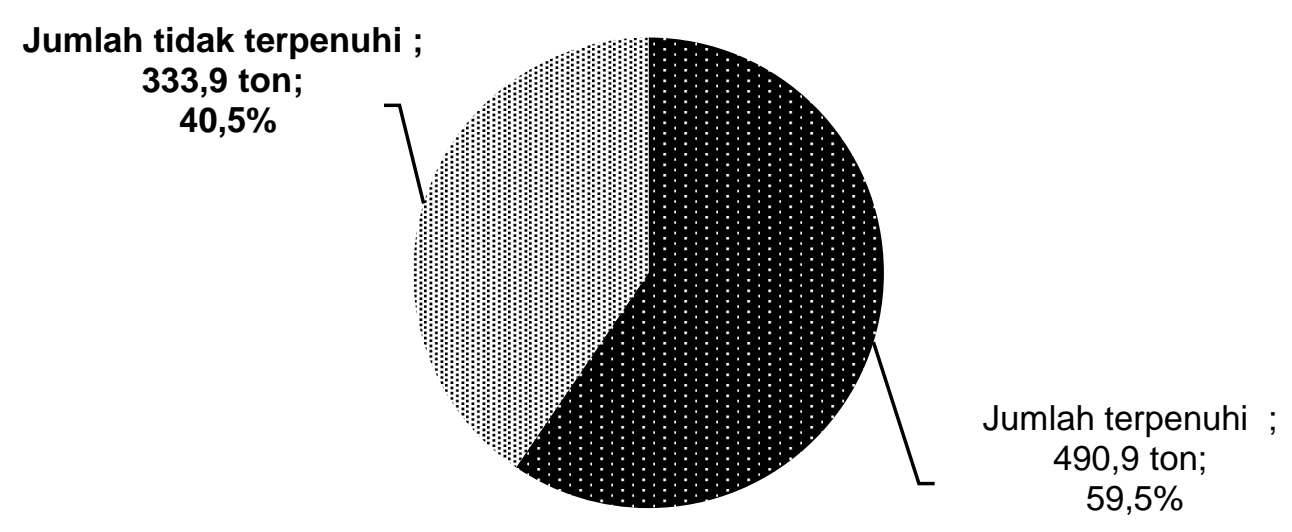

Sumber: Industri pemindangan ikan di PPP Tasik Agung 2018

Gambar 2 Pemenuhan ikan bahan baku per bulan (ton;\%) pada industri pengolahan ikan pindang di PPP Tasik Agung tahun 2018.

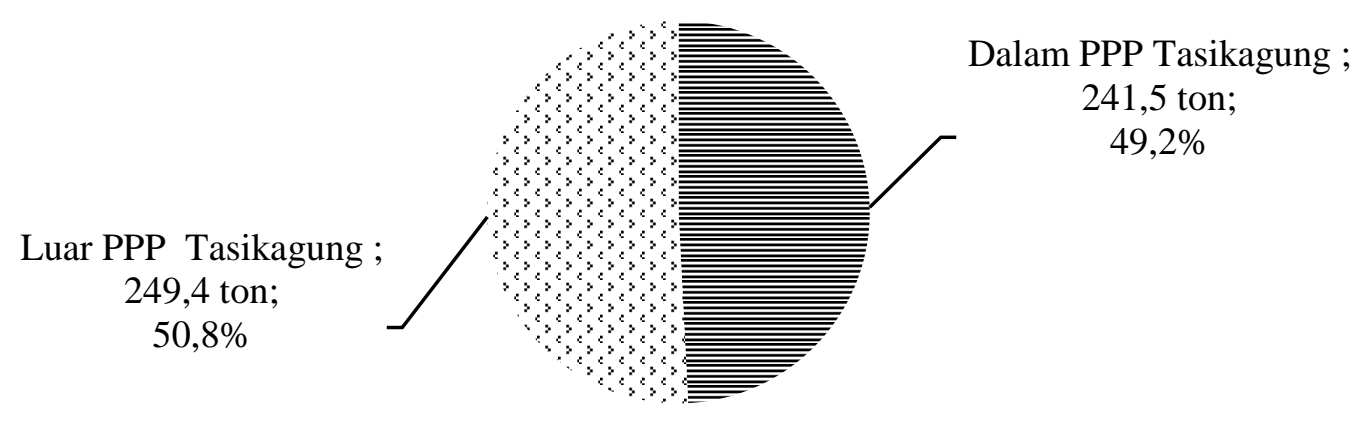

Sumber: Industri pemindangn ikan di PPP Tasik Agung 2018

Gambar 3 Pemenuhan ikan bahan baku per bulan (ton;\%) pada industri pindang menurut asal lokasi ikan di PPP Tasik Agung 2018.

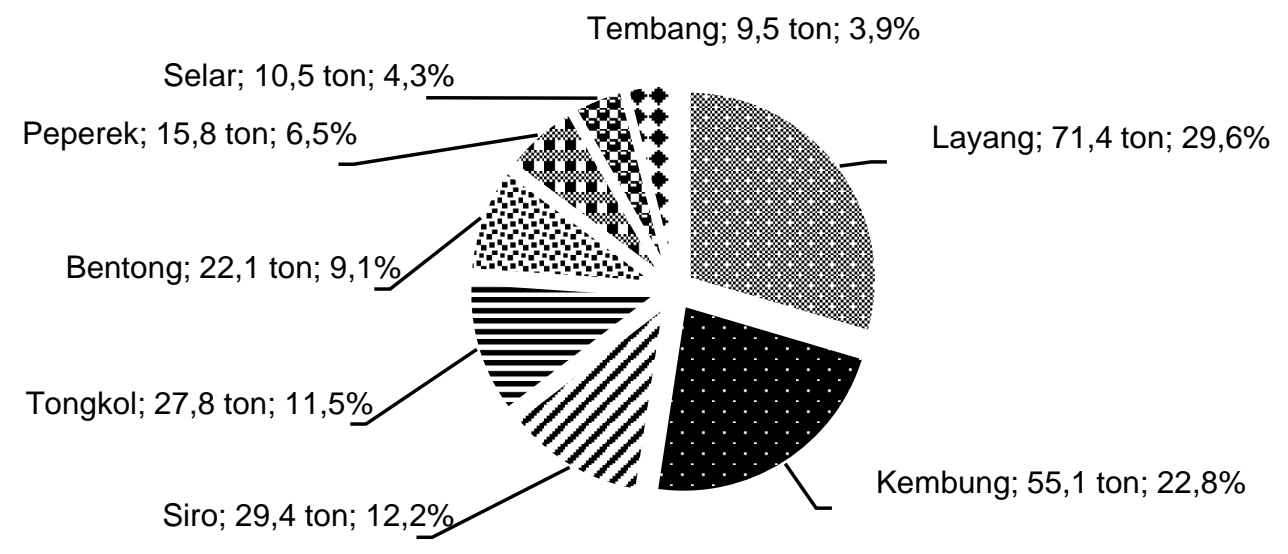

Sumber: Industri pemindangn ikan di PPP Tasik Agung 2018

Gambar 4 Komposisi ikan bahan baku industri pengolahan pindang per jenis ikan (ton;\%) yang berasal dari dalam PPP Tasik Agung tahun 2018. 


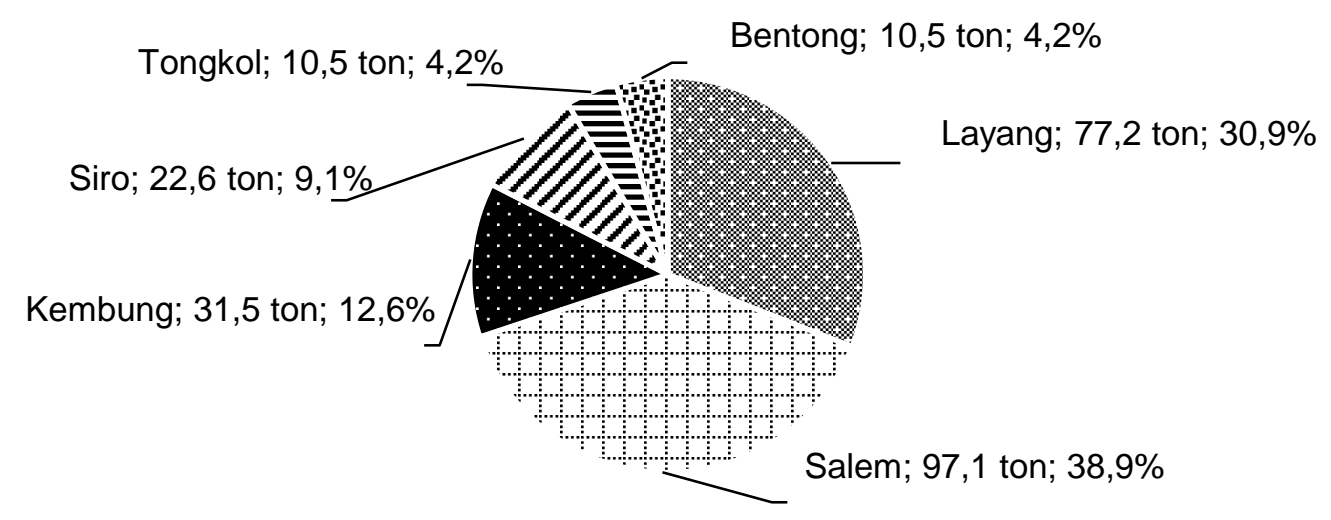

Sumber: Industri pemindangan ikan di PPP Tasik Agung 2018

Gambar 5 Komposisi ikan bahan baku industri pengolahan pindang per jenis ikan (ton;\%) yang berasal dari luar PPP Tasik Agung tahun 2018.

\section{Industri Pengolahan Ikan Pindang di PPP Tasik Agung Rembang dan Wilayah Pendistribusian Produknya}

Terdapat 20 unit IPI pindang di PPP Tasik Agung Rembang pada tahun 2015 (PPP Tasik Agung 2016), yang menyebar di sekitar pelabuhan. Namun berdasarkan wawancara terhadap pengurus kelompok usaha pindang di PPP Tasik Agung, hanya 11 unit yang aktif beroperasi di tahun 2017. Pada saat penelitian dilaksanakan, dari 11 unit tersebut hanya ditemukan 7 (tujuh) unit diantaranya yang sedang aktif berproduksi; atau terjadi penurunan $45,0 \%$ dari jumlah unit IPI pindang yang aktif beroperasi pada periode tahun 2015-2017.

Pengolahan ikan pindang adalah termasuk pengolahan ikan secara tradisional yang dikelola oleh anggota keluarga secara turuntemurun (Thaheer et al. 2010; Muriati et al. 2011 dan Darmadi et al. 2018), demikian pula pengolahan pindang di PPP Tasik Agung; yang membuat masyarakat di sekitar pelabuhan menguasai cara pengolahan ikan tersebut. Oleh karena itu, IPI pindang di PPP Tasik Agung Rembang mempekerjakan masyarakat sekitar sebagai tenaga kerja yang didominasi oleh ibu rumah tangga.

Berdasarkan tahapan proses pengolahan pindang (Hamidah et al. 2018), maka pengolahan pindang di PPP Tasik Agung termasuk kategori proses pengolahan ikan pindang cue, yaitu pengolahan yang dilakukan dengan cara perebusan dan pemberian garam ke dalam air mendidih. Perebusan ikan dilakukan sekaligus bersama wadah ikan dari bambu yang disebut besek; berisikan 2-3 ekor per besek. Hal ini sesuai dengan penelitian Junianingsih (2015);
Novianti et al. (2017) dan Damayanti (2016) dimana disebutkan bahwa perebusan ikan dilakukan pada wadah besek yang berisi 2-5 ekor ikan yang berukuran relatif sama. Ikan yang dijadikan pindang cue merupakan ikan berukuran kecil. Selain garam, digunakan juga tawas untuk membersihkan sisa kotoran yang menempel pada tubuh ikan dengan perbandingan 100 liter air, $50 \mathrm{~kg}$ garam, dan 3,0 \% tawas; dan lama perebusan 15-20 menit. Lama perebusan tersebut membuat produk ikan pindang hanya mampu disimpan selama 3-5 hari, karena kadar air yang meningkat sehingga akivitas pembusukan juga semakin tinggi (Ako 2016; Handayani et al. 2017; Kristianto et al. 2017 dan Putra et al. 2019).

Produk ikan pindang dari pelabuhan ini didistribusikan dan dipasarkan secara luas ke berbagai kota/kabupaten di provinsi-provinsi Jawa Tengah, Jawa Timur dan DI Yogyakarta, terutama ke pasar-pasar tradisionalnya. Damayanti (2015) dan Telaumbanua (2012) menyatakan bahwa Jawa Tengah, Yogyakarta, dan Jawa Timur merupakan daerah-daerah pemasaran produk ikan pindang. Pemasaran produk pindang (Gambar 6) dilakukan keenam kota/ kabupaten lainnya di Provinsi Jawa Tengah selain Kabupaten Rembang, yaitu Kabupaten Blora, Kabupaten Semarang, Kota Semarang, Kabupaten Jepara, Kabupaten Kudus, dan Kota Surakarta, selain itu juga ke Kota Surabaya Provinsi Jawa Timur, dan Kota Yogyakarta Provinsi DI Yogyakarta.

\section{Kebutuhan Ikan Bahan Baku menurut Jenis, Jumlah, dan Mutu Ikan Bahan Baku pada Industri Ikan Pindang di PPP Tasik Agung Rembang}


Kebutuhan IBB dapat dibagi menjadi tiga yaitu kebutuhan IBB menurut jenis, jumlah, dan mutu IBB. Jumlah IBB yang dibutuhkan oleh ke7 unit IPI pindang di PPP Tasik Agung Rembang berjumlah 824,8 ton/bulan atau $9.897,6$ ton/ tahun. Adapun jumlah yang terpenuhi dari seluruh sumber pemenuhan baik dari dalam PPP Tasik Agung maupun dari luar PPP Tasik Agung hanya mencapai 490,9 ton/bulan atau $5.890,8$ ton/tahun atau $59,5 \%$ dari jumlah keseluruhan kebutuhan IBB. Bila jumlah kebutuhan tersebut dirinci menurut jenis ikan, maka kebutuhan IBB terbesar adalah jenis ikan layang 257,3 ton/bulan atau $3.087,6$ ton/tahun $(31,2 \%)$; disusul kembung 168,0 ton/bulan atau 2.016,0 ton/tahun $(20,4 \%)$, dan siro 94,5 ton/bulan atau $1.134,0$ ton/tahun $(11,5 \%)$. Oleh karena jenis ikan salem adalah pengganti kekurangan jenis ikan layang, maka sebenarnya kebutuhan IBB layang adalah 380,7 ton/bulan atau $4.568,4$ ton/tahun (46,2\%).

Kebutuhan IBB per jenis ikan berkisar 9,5257,3 ton/bulan atau $114,0-3.087,6$ ton/tahun per jenis ikan, sedangkan jumlah yang terpenuhi memiliki kisaran 9,5-148,6 ton/bulan atau 114,0$1.783,2$ ton/tahun per jenis ikan. Hal ini menunjukkan bahwa tidak semua jenis IBB yang dibutuhkan oleh IPI pindang di PPP Tasik Agung terpenuhi jumlahnya, yaitu hanya sekitar $57,8 \%$ IBI yang tersedia di PPP Tasik Agung. Bila kebutuhan IBB dirinci per unit IPI pindang, maka rata-rata kebutuhan IBB pindang per unit per bulan adalah 117,8 ton/unit/bulan atau 1.413,9 ton/unit/tahun. Rata-rata tidak terpenuhinya kebutuhan IBB dari PPP Tasik Agung per unit IPI pindang per bulan adalah 47,7 ton/unit/bulan atau 572,4 ton/unit/tahun.

\section{Mutu ikan bahan baku yang dibutuhkan industri pengolahan ikan}

Mutu IBB merupakan salah satu hal penting yang harus diperhatikan oleh industri pemin- dangan ikan karena harga jual produk olahan ikan pindang juga sangat ditentukan oleh mutu IBB-nya. Berdasarkan wawancara kepada responden pengelola unit IPI pindang di PPP Tasik Agung diketahui bahwa IBB yang bermutu baik adalah ikan segar dan memiliki tekstur daging yang padat. Ikan bahan baku yang bermutu baik akan menghasilkan produk ikan pindang yang utuh dan tidak mudah rusak sedangkan ikan yang bermutu kurang baik akan mengalami kerusakan pada proses produksi.

Berdasarkan Tabel 2 diketahui bahwa secara umum mutu ikan IBB pada IPI memiliki nilai kisaran antara 5,5-8,2 skala organoleptik dengan nilai rata-rata 6,3 dan simpangan 0,5 skala organoleptik. Menurut Standar Nasional Indonesia (SNI) Nomor 2729: 2013 bahwa ikan yang memiliki nilai kisaran rata-rata 6-7 skala organoleptik, termasuk kedalam kelompok ikan yang memiliki mutu sedang dan yang memiliki nilai kisaran rata-rata 7-8 skala organoleptik, termasuk kedalam kelompok ikan yang bermutu baik (Badan Standarisasi Nasional 2013). Dapat dikatakan bahwa rata-rata IBB pada IPI pindang memiliki mutu sedang kecuali IBB yang berasal dari impor, memiliki mutu baik.

Mutu ikan untuk jenis ikan salem mendapatkan nilai tertinggi dengan nilai ratarata 8,2 skala organoleptik atau bermutu baik. Hal ini sesuai dengan penelitian Pane (2010); Deni (2015); Najah et al. (2015); dan Syafitri et al. (2016) yang menyebutkan bahwa ikan yang memiliki nilai mutu rata-rata $\geq 8,0$ dalam skala organoleptik adalah bermutu segar. Ikan yang memperoleh nilai terendah adalah ikan tembang diikuti oleh ikan tongkol dengan nilai masingmasing 5,5 dan 5,7 skala organoleptik yang berarti bermutu kurang baik. Jenis ikan layang, kembung, bentong, siro, selar dan peperek berada pada nilai kisaran rata-rata 6,0-6,5 atau bermutu sedang.

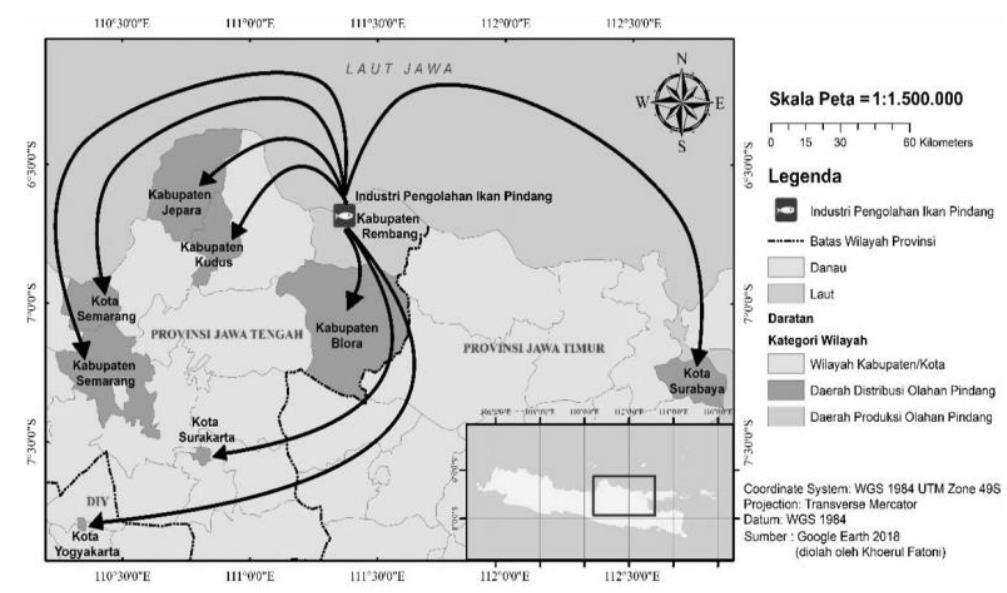

Gambar 6 Peta pemasaran produk ikan pindang pada IPI pindang di PPP Tasik Agung Rembang tahun 2018 
Tabel 1 Jumlah kebutuhan dan keterpenuhan ikan bahan baku (ton/bulan) seluruh unit IPI pindang menurut jenis ikan di PPP Tasik Agung Tahun 2018

\begin{tabular}{lcccccc}
\hline \multirow{2}{*}{$\begin{array}{c}\text { Jenis Ikan Bahan } \\
\text { Baku }\end{array}$} & \multicolumn{2}{c}{ Jumlah Kebutuhan } & \multicolumn{2}{c}{ Jumlah Terpenuhi } & \multicolumn{2}{c}{ Jumlah tidak terpenuhi } \\
\cline { 2 - 7 } & (ton/bulan) & (\%) & (ton/bulan) & (\%) & (ton/bulan) & $(\%)$ \\
\hline Layang & 257,3 & 31,2 & 148,6 & 57,8 & 108,7 & 42,2 \\
Kembung & 168,0 & 20,4 & 86,6 & 51,5 & 81,4 & 48,5 \\
Salem & 123,4 & 15,0 & 97,1 & 78,7 & 26,3 & 21,3 \\
Siro & 94,5 & 11,5 & 52,0 & 55,0 & 42,5 & 45,0 \\
Tongkol & 72,4 & 8,8 & 38,3 & 52,9 & 34,1 & 47,1 \\
Bentong & 63,0 & 7,6 & 32,6 & 51,7 & 30,4 & 48,3 \\
Selar & 21,0 & 2,5 & 10,5 & 50,0 & 10,5 & 50,0 \\
Peperek & 15,7 & 1,9 & 15,7 & 100,0 & 0,0 & 0,0 \\
Tembang & 9,5 & 1,2 & 9,5 & 100,0 & 0,0 & 0,0 \\
\hline Jumlah & 824,8 & 100,0 & 490,9 & - & 333,9 & - \\
\hline Persentase (\%) & 100,0 & - & 59,5 & - & 40,5 & - \\
\hline Kisaran & $9,5-257,3$ & $1,2-31,2$ & $9,5-148,6$ & $50,0-100,0$ & $0,0-108,7$ & $0,0-50,0$ \\
\hline Sumber: Data peneliti 2018 & & & & &
\end{tabular}

Tabel 2 Mutu ikan bahan baku pindang pada industri pengolahan pindang di PPP Tasik Agung tahun 2018

\begin{tabular}{lccc}
\hline \multirow{2}{*}{ Jenis ikan } & \multicolumn{3}{c}{ Mutu IBB (Skala organoleptik) } \\
\cline { 2 - 4 } & Kisaran & Rata - rata & Simpangan \\
\hline Layang & $4-7$ & 6,0 & 0,5 \\
Kembung & $4-8$ & 6,1 & 0,6 \\
Bentong & $5-7$ & 6,5 & 0,6 \\
Salem & $7-9$ & 8,2 & 0,6 \\
Siro & $5-7$ & 6,0 & 0,5 \\
Tongkol & $5-7$ & 5,7 & 0,5 \\
Tembang & $4-6$ & 5,5 & 0,6 \\
Selar & $5-7$ & 6,1 & 0,4 \\
Peperek & $5-7$ & 6,3 & 0,5 \\
\hline Kisaran & $4-9$ & $5,5-8,2$ & $0,4-0,6$ \\
\hline Rata-rata & - & 6,3 & 0,5 \\
\hline
\end{tabular}

Keterangan: IBB: Ikan bahan baku

Sumber: Data peneliti 2018

\section{PEMBAHASAN}

Ikan bahan baku pada industri pemindangan ikan di PPP Tasik Agung Rembang terdiri dari IBB utama dan IBB tambahan. Ikan bahan baku utama pada industri pemindangan ikan di PPP Tasik Agung Rembang adalah jenis layang. Jenis ikan lainnya merupakan jenis IBB tambahan yang digunakan sebagai pengganti IBB utama apabila industri pemindangan kekurangan jenis IBB utama. Ikan layang merupakan jenis ikan yang paling dominan didaratkan di PPP Tasik Agung, sehingga ikan tersebut dijadikan sebagai IBB utama IPI Pindang. Seperti juga telah dinyatakan dalam penelitian Fauziah et al. (2014); Deswati dan Muhadjir (2015);
Hermana et al. (2018) Viyanti et al. (2019) bahwa ikan jenis layang merupakan komoditas utama bahan baku pada industri pindang.

Ikan bahan baku IPI Pindang di PPP Tasik Agung Rembang diperoleh baik dari dalam PPP Tasik Agung maupun dari luar PPP Tasik Agung. Ikan bahan baku perlu didatangkan dari luar PPP Tasik Agung oleh IPI pindang karena jumlah ikan bahan baku yang didapatkan dari dalam PPP Tasik Agung belum mampu mencukupi kebutuhan IBB pindang di pelabuhan tersebut. Berdasarkan hasil wawancara dengan pemilik IPI pindang di PPP Tasik Agung, diketahui bahwa IPI pindang di PPP Tasik Agung mengalami kekurangan IBB utama yaitu ikan jenis 
layang. Hal ini terjadi karena jenis ikan tersebut mengalami penurunan volume produksi. Penurunan ini terjadi dikarenakan kekurangan IBB pindang, yang diduga disebabkan oleh menurunnya produksi ikan layang hasil tangkapan di PPP Tasik Agung Rembang. Samekto (2019) juga menyatakan hal yang sama yaitu terjadi penurunan volume produksi ikan yang drastis di PPP Tasik Agung pada tahun 2015-2017 dari 35.122 .383 ton/tahun menjadi 15.741 .780 ton/ tahun. Merdiana et al. (2018) menambahkan bahwa cuaca ekstrim mengakibatkan nelayan saat itu tidak berani melaut. Hal tersebut kemudian berdampak pada naiknya harga IBB pindang sehingga membuat sebagian pengolah pindang memilih tidak berproduksi.

Pada tahun 2016 volume produksi ikan layang sebesar $5.620,0$ ton, akan tetapi pada tahun 2017 hanya menghasilkan volume produksi sebesar 2.065,6 ton atau menurun 36,8\% dibanding tahun sebelumnya. Lubis et al. (2013) menyebutkan bahwa kurangnya IBB dapat diantisipasi dengan mengganti IBB tersebut dengan jenis IBB lainnya sesuai dengan kebutuhan industri. Hal tersebut telah dilakukan oleh para pengolah pindang di sekitara PPP Tasik Agung, baik ikan-ikan yang berasal dari pelabuhan-pelabuhan sekitar PPP Tasik Agung maupun yang berasal dari impor. Hal ini juga dilakukan oleh Pelabuhan Boulogne-sur-Mer (Prancis) yang mengimpor sebagian bahan bakunya dari Negara Eropa lainnya untuk memenuhi kebutuhan bahan baku industri pengolahan ikan yang berada di pelabuhan perikanan tersebut (Lubis 2011). Selain itu, Hutapea et al. (2017) menyampaikan strategi mengatasi masalah pemenuhan kebutuhan bahan baku tuna untuk IPI di Pelabuhan Perikanan Samudera (PPS) Nizam Zachman Jakarta adalah dengan mendatangkan ikan bahan baku dari daerah lain, yaitu Bitung, Cilacap, Malang, dan Palabuhanratu. Pemenuhan kebutuhan IBB IPI dengan cara mendatangkan IBB dari tempat pendaratan lain dapat lebih cepat karena dilakukan segera tanpa harus menambah jumlah armada penangkapan ikan (Hamzah et al. 2015).

Aktivitas pembelian IBB impor juga dilakukan oleh pengusaha IPI Pindang di PPP Tasik Agung Rembang untuk jenis ikan salem. Pembelian ikan salem impor dari China dilakukan untuk memenuhi kebutuhan IBB. Berdasarkan wawancara dengan pengelola IPI Pindang pembelian ikan salem impor dilakukan karena jenis ikan salem tidak didaratkan di PPP Tasik Agung Rembang. Pradipta et al. (2014) menyebutkan bahwa ikan salem memiliki habitat di perairan subtropis dan distribusinya tersebar luas di Samudera Pasifik. Hal ini didukung oleh penelitian Yasuda et al. (2014) yang menyatakan bahwa daerah penangkapan ikan spesies
Scomber japonicus (salem) berada di Laut Cina Timur. Oleh karena itu, ikan jenis salem tidak ditemukan di Indonesia yang mengakibatkan pengusaha IPI pindang di PPP Tasik Agung Rembang harus membeli ikan salem impor dari pedagang grosir yang melakukan kegiatan impor ikan salem. Hal yang sama juga dilakukan oleh pengolah ikan pindang di PPP Muncar yaitu ketika jumlah IBB di PPP Muncar jumlahnya sedikit sehingga para pengolah mendatangkan sebagian IBB dari luar daerah seperti Grajagan, Tuban, dan Puger; terkadang membeli IBB salem impor yang berasal dari dari China atau Taiwan Lubis et al. (2013).

Ikan salem impor yang terdapat di industri pengolahan pindang merupakan ikan yang berasal dari cold storage dalam bentuk beku, sehingga mutu ikan tetap terjaga. Ikan dalam bentuk beku memiliki mutu yang baik dengan bentuk yang masih kencang, kulit mulus (tidak sobek), dan isi perut yang belum keluar (Astuti 2015). Kedelapan jenis ikan lainnya diperoleh dari pelabuhan perikanan dan pedagang penyuplai ikan secara langsung, sehingga ikan dapat mengalami penurunan mutu karena penanganan ikan yang kurang baik. Penanganan ikan yang kurang baik dapat beresiko meningkatnya bakteri pada ikan sehingga mutu ikan menurun (Luu et al. 2015; Maruka et al. 2017). Berdasarkan mutu IBB, dapat dikatakan bahwa dari 9 jenis IBB hasil temuan dalam penelitian ini, hanya jenis ikan salem yang memiliki mutu baik, 6 jenis ikan lainnya bermutu sedang, dan 2 jenis lainnya bermutu kurang baik.

\section{KESIMPULAN}

Kebutuhan IBB IPI pindang di PPP Tasik Agung berjumlah 824,8 ton/bulan dan terdiri dari 9 jenis ikan yaitu layang, kembung, salem, siro, tongkol, bentong, selar, peperek, dan tembang. Kebutuhan IBB IPI pindang hanya terpenuhi sebesar 490,9 ton/bulan (59,5\%). Adapun sumber pemenuhan IBB IPI pindang di PPP Tasik Agung, sebanyak 241,5 ton/bulan $(49,2 \%)$ berasal dari dalam PPP Tasik Agung, dan sebanyak 249,4 ton/bulan $(50,8 \%)$ berasal dari luar PPP Tasik Agung. Layang merupakan jenis ikan yang paling banyak dibutuhkan sebagai IBB IPI pindang di pelabuhan ini dengan jumlah kebutuhan 380,7 ton/bulan. Berdasarkan mutu ikan dari 9 jenis IBB IPI pindang hanya jenis ikan salem yang bermutu baik, 6 jenis lainnya bermutu sedang, dan 2 jenis lainnya bermutu kurang baik.

\section{SARAN}

Pengelola PPP Tasik Agung perlu meningkatkan volume produksi IBB IPI Pindang, 
salah satunya adalah dengan mendatangkan ikan dari pelabuhan lain di sekitar PPP Tasik Agung. Cara ini lebih memungkinkan untuk dilakukan dibandingkan dengan menambah effort penangkapan. Selain itu, mutu ikan yang didaratkan maupun yang didatangkan ke PPP Tasik Agung perlu lebih diperhatikan.

\section{UCAPAN TERIMA KASIH}

Ucapan terima kasih dan penghargaan diberikan kepada Dinas Kelautan dan Perikanan Kabupaten Rembang, Pengelola Pelabuhan Perikanan Pantai Kabupaten Rembang, dan Pemilik industri pengolahan ikan pindang di PPP Tasik Agung yang telah memberikan banyak informasi pada penelitian ini.

\section{DAFTAR PUSTAKA}

Adhitama MR. 2018. Strategi Pengembangan Sentra UMKM Ikan Pindang di Desa Tasik Agung Kabupaten Rembang. Economics development analysis journal. 7(2): 203209.

Adrian F. 2013. Identifikasi Potensi Pasar Produk Olahan Pindang Wilayah Pamoyanan Bogor. Jurnal MAGMA Magister Manajemen. 1(1): 101-110.

Ako J. 2016. Penambahan Rimpang Jahe (Zingiber Offcinale) dan Lama Penyimpanan terhadap Mutu Pindang Kembung. Jurnal Sains Dan Teknologi Pangan. 1(1): 1-7.

Assadad L, Utomo BSB. 2011. Pemanfaatan Garam dalam Industri Pengolahan Produk Perikanan. Jurnal Squalen. 6(1): 26-37.

Astuti AD. 2015. Penerapan Produksi Bersih di Industri Pemindangan Ikan Desa Bajomulyo Kecamatan Juwana, Pati. Jurnal Litbang. 11(1): 14-22.

[BSN] Badan Standarisasi Nasional. 2013. Standar Nasional Indonesia Nomor 2729 : 2013 Tentang Ikan Segar [internet]. [Diunduh pada 2019 Juli 17]. Tersedia pada:

http://sispk.bsn.go.id/SNI/DetailSNI/9480.

Damayanti HO. 2015. Rantai Pemasaran Ikan Pindang di Kabupaten Pati. Jurnal Litbang. 11(1): 23-30.

Damayanti HO. 2016. Kelayakan Usaha Insdutri Ikan Pindang Skala Rumah Tangga di
Kabupaten Pati. Jurnal Litbang. 12(1): 22-31.

Darmadi NM, Edi DGS, Kawan IM, Semariyani AAM, Sudiarta IW. 2018. The Changes in Protein Content, Moisture Content, and Organoleptic Pindang of Auxis Thazard Due to Re-Boiling Stored in Cold Temperatures. International Journal of Life Sciences. 2(3): 75-85.

Deni S. 2015. Karakteristik Mutu Ikan Selama Penanganan pada Kapal KM. Cakalang. Agrikan: Jurnal Agribisnis Perikanan. 8(2): 72-80.

Deswati RH, Muhadjir. 2015. Dukungan Aspek Produksi dalam Sistem Logistik Ikan Nasional (SLIN) di Kota Kendari, Sulawesi Tenggara. Jurnal Sosial Ekonomi Kelautan dan Perikanan. 10(2): 191-202.

Dinas Kelautan dan Perikanan Kabupaten Rembang. 2018. Statistik Perikanan 2017. Rembang: Dinas Kelautan dan Perikanan Kabupaten Rembang.

Fauziah N, Swastawati F, Rianingsih L. 2014. Kajian Efek Antioksidan Asap Cair terhadap Oksidasi Lemak Ikan Pindang Layang (Decapterus sp.) Selama Penyimpanan Suhu Ruang. Jurnal Pengolahan dan Bioteknologi Hasil Perikanan. 3(4): 71-76.

Hamzah A, Pane AB, Lubis E, Solihin I. 2015. Potensi Ikan Unggulan sebagai Bahan Baku Industri Pengolahan di PPN Karangantu. Marine Fisheries. 6(1): 45-48.

Handayani BR, Kusumo BD, Werdiningsih W, Rahayu TI, \& Hariani. 2017. Kajian Mutu Organoleptik dan Daya Simpan Pindang Tongkol dengan Perlakuan Jenis Air dan Lama Pengukusan. Jurnal IImu Dan Teknologi Pangan. 3(1): 195-199.

Hanidah II, Santoso MB, Marwadati E, Setiasih IS. 2018. Pemberdayaan Pengrajin "Pindang Cue" Desa Jayalaksana melalui Teknik Pengemasan. Jurnal Aplikasi Ipteks untuk Masyarakat.7(1): 14-18.

Hermana I, Kusmarwati A, Yennie Y. 2018. Isolasi dan Identifikasi Kapang dari Ikan Pindang. Jurnal Pascapanen dan Bioteknologi Kelautan dan Perikanan. 13(1): 7990.

Hutapea RYF, Solihin I, Nurani TW. 2017. Peran Pelabuhan Perikanan Samudera Nizam Zachman Jakarta dalam mendukung industri tuna. Marine Fisheries. 8(2): 187198. 
Junianingsih I. 2015. Uji Kualitas Mutu Pindang Cue-Besek Ikan Layang (Decapterus sp.) di Desa Jangkar Kabupaten Situbondo. Jurnal IImu Perikanan. 6(2): 91-98.

[KKP] Kementerian Kelautan dan Perikanan. 2012. Peraturan Menteri Kelautan dan Perikanan Nomor 8 Tahun 2012 Tentang Kepelabuanan Perikanan [internet]. [diunduh 2019 Juli 30]. Tersedia pada: jdih.kkp.go.id/peraturan/per-08-men2012.pdf

[KKP] Kemeterian Kelautan dan Perikanan. 2013. Profil Kelautan dan Perikanan Provinsi Jawa Tengah untuk Mendukung Industrialisasi KP. Pusat Data Statistik dan Informasi Kementerian Kelautan dan Perikanan.

Kristianto $H$, Arbita AA, Soetedjo JNM, Bisowarno $\mathrm{BH}$, Pricillia S, dan Priescilia $\mathrm{H}$. 2017. Kajian Awal Pengawetan Ikan Pindang Bandeng dan Mojang dengan Pengemasan Vakum di Desa Cukanggenteng. Jurnal Pengabdian Kepada Masyarakat. 23(2): 268-273.

Lubis E. 2011. Kajian Peran Strategi Pelabuhan Perikanan terhadap Pengembangan Perikanan Laut. AKUARTIK-Jurnal Sumberdaya Perairan. 5(2): 1-7.

Lubis E. 2012. Pelabuhan Perikanan. IPB Press. Bogor. 197 hal.

Lubis E, Nugroho T, Witry Septanty DB. 2013. Produksi Hasil Tangkapan sebagai Bahan Baku Industri Pengolahan : Kasus Pelabuhan Perikanan Pantai Muncar Kabupaten Banyuwangi. Buletin PSP. 1(21): 77-95.

Luu PH, Dunne MP, Pearse W, Davies B. 2015. Seafood Safety Compliance with Hygiene Regulations Within Vietnamese Domestic Distribution Chains. British Food Journal. 118(4): 777-794.

Maruka SS, Siswohutomo G, Rahmatu RD. 2017. Identifikasi Cemaran Bakteri Escherichia coli pada Ikan Layang (Decapterus russelli) Segar di Berbagai Pasar Kota Palu. Jurnal Mitra Sains. 5(1): 84-89.

Merdiana SE, Wibowo BA, Mudzakir AK. 2018. Analisis Kinerja Koperasi Unit Desa (KUD) Misoyo Mardi Mino dalam Usaha Pemberdayaan Masyarakat Nelayan di Kecamatan Sarang, Kabupaten Rembang. Journal of Fisheries Resources
Utilization Management and Technology. 7(1): 28-36.

Muriati NM, Hadiwijaya WG. 2011. Analisis Strategi Pengembangan Sentra Pengolahan Hasil Perikanan di Desa Kusamba Kabupaten Klungkung: Ditinjau dari Perspektif Bisnis dan Lingkungan. Jurnal Pertanian Berbasis Keseimbangan Ekosistem. 1(2): 1-14.

Nababan R, Wibowo BA, Boesono H. 2014. Analisis Faktor-Faktor yang Mempengaruhi Harga Ikan Layang (Decapterus Spp) yang Tertangkap dengan Alat Tangkap Mini Purse Seine di Pelabuhan Perikanan Pantai Tasik Agung Rembang Jawa Tengah. Journal of Fisheries Utiliztion Resources Management and Technology. 3(3): 113-121.

Najah RA, Lubis E, Solihin I, Pane AB. 2015. Kajian Nilai Pasar Produksi Hasil Tangkapan di PPS Nizam Zachman dan PPI Muara Angke. Marine Fisheries. 6(2): 155-167.

Naya DAB, Wijayanto D, dan Sardiyatmo. 2017. Analisis komoditas unggulan perikanan tangkap di Provinsi Jawa Tengah. Journal of Fisheries Reources Utilization Management and Technology. 6(3): 37-46.

Novianti SD, Sulistiyani, Darundiati YH. 2017. Hubungan Antara Pengendalian Titik Kritis Pengolahan terhadap Keberadaan Bakteri E.Coli Pindang Ikan Layang di Desa Tasik Agung Kabupaten Rembang. Jurnal Kesehatan Masyarakat. 5(5): 881890.

Pane, AB. 2010. Kajian Kekuatan Hasil Tangkapan : Kasus Pelabuhan Perikanan Nusantara (PPN) Pelabuhanratu Sukabumi. Jurnal Mangrove dan Pesisir. 10(1): 8-19.

[PPP] Pelabuhan Perikanan Pantai Tasik Agung Rembang. 2016. Laporan Tahunan PPP Tasik Agung Rembang 2015. Rembang: Pelabuhan Perikanan Pantai Tasik Agung Rembang.

[PPP] Pelabuhan Perikanan Pantai Tasik Agung Rembang. 2018. Laporan Tahunan PPP Tasik Agung Rembang 2017. Rembang: Pelabuhan Perikanan Pantai Tasik Agung Rembang.

Pradipta RE, Subekti S, Kismiyati. 2015. Identifikasi dan Prevalensi Cacing pada Saluran Pencernaan Ikan Salem 
(Scomber Japonicus) di Pangkalan Pendaratan Ikan Muara Angke Jakarta Utara. Jurnal Ilmiah Perikanan dan Kelautan. 7(1): 109-114.

Putra IGPFRS, Juliantara IKP, Sukmayanti NLPA. 2019. Pemeriksaan Kualitas Mutu dan Cemaran Mikrobiologi Ikan Pindang Layang (Decapterus Spp) di Pasar Mambal Market, Bali. Jurnal IImiah Medicamento. 5(1): 16-20.

Ratri ME. 2013. Produksi ikan pindang mampu capai target [Internet]. [diakses 2019 Juli 29]. Tersedia pada: htttp://www.google.com/amp/amp.kontan. co.id /news/produksi-ikan-pindangmampu-capai-target.

Ridho MA. 2019. Analisis usaha pengolahan petis ikan di Kecamatan Pasongsongan Kabupaten Sumenep. Prosiding: Seminar Nasional Ekonomi dan Teknologi 2019. Universitas Wiraraja Sumenep: 12 September 2019. 493-498.

[SETNEG] Kementerian Sekretariat Negara Republik Indonesia. 2009. Undangundang nomor 45 tahun 2009 tentang Perikanan [Internet]. [diunduh 2019 juli 30]. Tersedia pada : https://peraturan.bpk.go.id/Home/Details/ 38790/uu-no-45-tahun-2009.

Samekto AA. 2019. Analisis Faktor-Faktor yang Mempengaruhi Keselamatan Pelayaran Kapal Penangkapan Ikan di Pelabuhan Tasik Agung Rembang. Jurnal Saintek Maritim. 19(2): 196-202.

Setiani, Ibrahim MN, Ishamu KT. 2019. Pengaruh Penambahan Daun Kusambi (Schleichera oleosa) dan Daun Kedon- dong (Spondias pinnata) terhadap Kualitas Ikan Kembung (Rastrellinger kanagurta) Pindang. Jurnal Fish Protech. 2(1): 27-37.

Syafitri, Metusalach, Fahrul. 2016. Studi Kualitas Ikan Segar Secar Organoleptik yang Dipasarkan di Kabupaten Jeneponto. Jurnal IPTEKS PSP. 3(6): 544-552.

Telaumbanua HPS. 2012. Identifikasi Kandungan Formalin pada Ikan Pindang di Pasar Tradisional dan Modern Kota Semarang. Jurnal Kesehatan Masyarakat, 1(2): 983-994.

Thaheer H, Hasibuan S, Mumpuni S. 2010. Model Resiko Keamanan Pangan Produk Pindang pada UMKM Pengolahan Ikan Rakyat. Jurnal PASTI. 9(3): 275-285.

Viyanti R, Sumardianto, Suharto S. 2019. Penggunaan Air Pindang Ikan Berbeda terhadap Kandungan Asam Glutamat pada Petis. Jurnal PENA Akuatika. 18(2): 23-33.

Widria Y. 2019. Pemindangan, 15-20 mentteknik pengolahan ikan yang memiliki potensi meningkatkan konsumsi ikan nasional [internet]. [diakses 2019 juli 30]. Tersedianya pada: https://kkp.go.id/djpdspkp/bbp2hp/artikel/ 11443-pemindangan-teknik-pengolahanikan-yang-memiliki-potensi-meningkatkan-konsumsi-ikan-nasional.

Yasuda T, Yukami R, dan Oshimo S. 2014. Fishing ground hotspots reveal long-term variation in chub mackerel Scomber japonicus habitat in the East China Sea. Marine Ecology Progress Series. 501: 239-250. 